\title{
THE EFFECT OF CASEIN CONTENT IN RAW MILK ON RETENTION OF BASIC INGREDIENTS IN PASTEURIZED MILK AND RAW CURD
}

Department of Cattle, Sheep Breeding and Milk Evaluation, Siedlce University of Natural Sciences and Humanities, Poland

\begin{abstract}
The aim of the experiment was to assess the effect of casein content in milk on cheese yield and the ability to retain the basic ingredients in the raw curds and their migration to whey. The research material was 61 samples of pasteurized milk from Holstein-Friesian cows. Only raw material of acidity in the range of $6.5-7.5^{\circ} \mathrm{SH}$ and meeting the cytological standards was included in the experiments. Milk was assigned to one of one of two classes of casein content (CCA). The threshold value of division of the raw material was set at $2.43 \%$. The content of protein, fat, dry matter, solids-not-fat was determined in pasteurized milk, whey, raw curd. The higher content of casein in raw milk had a positive effect on the retention of basic ingredients in the pasteurized milk, raw curd at the same time lower protein content in whey. More cheese mass was obtained from milk with higher casein content. For reasons of milk processing practice, it should be recognized that in case of milk produced for cheese-making, the casein level should be casein content exceeding the $2.43 \%$.
\end{abstract}

Key words: cow, casein, milk composition, whey, raw curd.

\section{INTRODUCTION}

One of the most important characteristics of milk is not the protein content, but the concentration of casein. Because this component plays an important role in cheese making and has interaction with whey components determines the quality and quantity of curd obtained (Correding and Dalgleish 1999; Dalgleish et al. 2002; Młynek et al. 2018). It has a large impact on dynamics of milk improvement and continuous development of milk processing. Often, however, breeding practice draws attention to the production (Havea et al. 2001; Sitkowska et al. 2009; Gustavsson et al. 2014) and the health of cows (Considine et al. 2002; Larsen et al. 2004; Larsen et al. 2006). In practise the composition and content of proteins, including $\mathrm{K}$-casein present in milk was less appreciated.

In the context of improving the production efficiency of ripening cheeses, an important aspect for the cheese industry is knowledge about the acceptable amount of casein contained in raw milk. Therefore, the aim of the experiment was to examine the relationship between casein content in milk and the retention of basic ingredients in milk after pasteurization and curd and their drainage into whey.

Corresponding author: Ewa Salamończyk, Department of Cattle, Sheep Breeding and Milk Evaluation, Siedlce University of Natural Sciences and Humanities, Bolesława Prusa 14, 08-110 Siedlce, Poland, e-mail: ewa.salamonczyk@uph.edu.pl, ORCID: 0000-0002-1393-9709 


\section{MATERIAL AND METHODS}

The experimental material consisted of 61 samples of raw milk, which were then pasteurized at $72^{\circ} \mathrm{C}$ for 30 seconds. The pasteurized milk cooled in a water bath at $30^{\circ} \mathrm{C}$ of The raw milk was collected in February, May and August 2014. Milk was derived from farms keeping Polish Holstein-Friesian cows, which were fed year-round the TMR system. Only raw material of acidity in the range of $6.5-7.5^{\circ} \mathrm{SH}$ and meeting the cytological standards was included in the experiments (Commission Regulation (EC) No 1662/2006). Milk before pasteurization was assigned to one of the classes of casein content (CC). The threshold value of division of the raw material was set at $2.43 \%$. The limit value of casein content in raw milk was determined on the basis of information on the distribution of characteristics in the analyzed milk samples.

The casein contents (Kjeldahl, PN-75/A-04018) were determined using methods recommended by the Association of Official Analytical Chemists (AOAC 1995). The content of K-casein was determined using a VARIAN liquid chromatograph (HPLC system consisted of a three-valve pump, automatic injection block, column thermostat, UV-detector). Casein precipitation and purification were conducted in an acetate buffer $\left(\mathrm{pH} 4.6 ; 20^{\circ} \mathrm{C}\right)$. The resulting isolate was transferred to a Tris- $\mathrm{HCl}$ buffer $\left(\mathrm{pH} 8.0 ; 20^{\circ} \mathrm{C}\right)$. Casein separation was performed on a $\mathrm{C} 18$ column (250 mm length $\times 4.6 \mathrm{~mm}$, Widepore $3.6 \mathrm{u}$; Phenomenex) at a flow rate of $1.5 \mathrm{ml} / \mathrm{min}$ (A: $0.1 \%$ aqueous trifluoroacetic acid [TFA in a ratio of $900: 1(\mathrm{v} / \mathrm{v}), \mathrm{B}: 0.1 \%$ TFA solution in acetonitrile a ratio of $900: 1(\mathrm{v} / \mathrm{v})$ ] for 25 minutes. Total run time: 30 minutes; column temperature: $40^{\circ} \mathrm{C}$; flow rate: $1.0 \mathrm{ml} / \mathrm{min}$; detection wavelength: $215 \mathrm{~nm}$; injection volume of the final sample solution: $20 \mathrm{ml}$. The solvent gradient program started at $20 \%$ of solvent $\mathrm{B}$, and was generated immediately after sample injection by increasing the proportion of solvent $B$ to $46 \%$ at the end of the run, and subsequently restored to the initial conditions in 2.4 minutes. The concentration of $\mathrm{K}$-casein was based on the calibration curve using the bovine $\mathrm{k}$-casein (SIGMA-ARDRICH). The equipment was controlled by a software (Varian Star) that controls the solvent gradient, data acquisition and data processing. All solutions were filtered through a nylon filter $(25 \mathrm{~mm}, 0.45 \mu \mathrm{m})$.

Cheese yield of the milk was evaluated on the basis of the quantity of the resulting curd mass. Coagulation of milk proteins was performed in milk heated to $30^{\circ} \mathrm{C}$. The procedure consisted of determining the weight of $30 \mathrm{ml}$ of milk placed in Falcon tubes and adding thereto $0.1 \mathrm{ml}$ of a $50 \%$ solution of $\mathrm{CaCl}_{2}$. It was mixed, $0.03 \mathrm{ml}$ of coagulant (lactic acid bacteria CesKa®-stAr C 07) - (1:30.000) was added, and left for 3 minutes. The tubes were put into a water bath at $50^{\circ} \mathrm{C}$, heated for 30 minutes and then transferred to a water bath at room temperature. Once cooled, the curd was centrifuged for 30 minutes at $2500 \mathrm{rpm}$ and $20^{\circ} \mathrm{C}$ chamber temperature. The resulting whey was decanted and the tubes with the cheese mass were turned upside down, on the filter paper to drain the whey residues. Drying time was $30 \mathrm{~min}$. Then the weight of the resultant curd was determined and its yield was calculated in relation to the weight of the milk (Jurczak 2005).

The results were verified statistically using analysis of variance, calculating the least squares means (LSM) and standard error of the mean (SEM). The correlation coefficients between the selected characteristics of pasteurized milk and the content of the main constituents of the curd and whey obtained therefrom were also calculated. Calculations were performed in the STATISTICA 10.0 software. All tests were estimated at the significance level $\alpha=0.01$. 


\section{RESULTS AND DISCUSSION}

The results shown in Table 1 indicated that the proportion of casein in raw milk (casein content class - CC) was associated with the total protein content in the milk subjected to pasteurization and the products formed during cheese production. Milk with CCA had $0.16 \%$ more protein $(P \geq 0.015)$ and $0.02 \%$ more $k$-casein $(P \geq 0.035)$. The milk with CCA also had a more favorable ratio of casein to protein, on average by $3.54 \%(P \geq 0.004)$ and a higher dry matter by $0.24 \%$ ( $P \geq 0.009$ ). The results show that there is a strong positive correlation between the casein in milk and protein content, dry matter content and solid-not-fat content in cheese $(0.370-0.782 ; P<0.05)$.

Table 1. Characteristics of pasteurized milk (LSM, SEM) in relation to different casein concentration in milk

\begin{tabular}{llllllll}
\hline \multirow{2}{*}{$\begin{array}{l}\text { Class of casein } \\
\text { content - CC }\end{array}$} & \multirow{n}{*}{$\mathrm{n}$} & \multicolumn{4}{c}{ Characteristics of pasteurized milk [\%] } & Casein/ protein \\
\cline { 3 - 6 } & & casein & protein & fat & k-casein & dry matter & \\
\hline $\mathrm{A}<2.43 \%$ & 26 & 2.350 & 3.280 & 4.070 & 0.260 & 11.910 & 71.760 \\
$\mathrm{~B} \leq 2.43 \%$ & 35 & 2.590 & 3.440 & 3.960 & 0.280 & 12.150 & 75.300 \\
SEM & & 0.102 & 0.030 & 0.050 & 0.010 & 0.050 & 0.380 \\
P-value & & 0.001 & 0.015 & 0.006 & 0.035 & 0.009 & 0.004 \\
\hline
\end{tabular}

Table 2 summarizes the results of the characteristics of the products made from pasteurized milk, depending on the $\mathrm{CC}$. It should be noted that the highest cheese curds yield was obtained from samples containing more than $2.43 \%$ casein. The strongest CC impact was recorded for the protein content of fresh cheese curd $(P \geq 0.001)$. The difference was found to be on average $0.84 \%$. Amenu and Deeth (2007) and Amenu (2004) found that reducing the level of casein to $0.1 \%$ in milk decreased the yield of cheddar-type cheese by $0.5 / 100 \mathrm{~kg}$. Barłowska et al. (2006) and Król et al. (2011) obtained similar concentration values of milk components derived from Holstein-Friesian cows, but pertaining to raw milk. The products tested by these authors contained an average of $13.15 \%$ dry matter, $3.41 \%$ total protein and $2.57 \%$ casein, while the detected ratio of protein to fat in the milk of these cows was $0.82 \%$. Similarly as in our study, Kowal (2013) also showed no effect of the production season on casein content in milk $(2.83-2.90 \%)$ and the protein/fat ratio $(0.80-0.83)$. However, as compared to own study, casein content found by this author was slightly higher.

Table 2. Chemical composition of raw cheese curds (LSM, SEM) with different casein concentrations

\begin{tabular}{lccrrrr}
\hline \multirow{2}{*}{$\begin{array}{c}\text { Class of casein } \\
\text { content - CC }\end{array}$} & $\mathrm{n}$ & $\begin{array}{c}\text { Cheese } \\
\text { curds yield } \\
{[\mathrm{kg}]}\end{array}$ & protein & fat & dry matter & solids-not-fat \\
\hline $\mathrm{A}<2.43 \%$ & 26 & 22.500 & 11.950 & 13.600 & 28.030 & 14.510 \\
$\mathrm{~B} \leq 2.43 \%$ & 35 & 23.700 & 12.790 & 14.130 & 29.720 & 15.520 \\
SEM & & 0.140 & 0.070 & 0.050 & 0.130 & 0.090 \\
P-value & & 0.009 & 0.001 & 0.025 & 0.004 & 0.039 \\
\hline
\end{tabular}

The separation of whey is one of the critical steps in the production of rennet cheeses, as the smallest parts of the curd outflow with draining whey. The correct curd formation and its structure is a factor favoring a lower loss of these structures (Chmura et al. 2002). Our studies, as, i.a., the work Correning and Dalgleish (1999), showed that the micellar casein structure 
and $\mathrm{k}$-casein content played a significant role in limiting losses resulting from whey separation. These relationships are confirmed by the data listed in Table 2. They indicate that from the milk with CCA, a curd was obtained with a $0.84 \%$ higher protein content $(P \geq 0.011)$, 0.53 higher fat content $(P \geq 0.025)$ and $1.01 \%$ solids-not-fat $(P \geq 0.039)$.

The results of St-Gelais and Hache (2005) research demonstrated that the coagulation process was much slower and the curd was clearly weaker in milk with a lower concentration of $\mathrm{k}$-casein. According to these authors, it was caused, i.a., by a higher drainage of the components along with the whey.

The proportion of the components analyzed in the whey (Table 3) indicated that the protein losses were higher in the milk classified as CCA. The whey obtained from this milk had a lower protein content by $0.09 \%(P \geq 0.016)$ and $0.11 \%$ lower dry matter $(P \geq 0.024)$. Walstra et al. (2006) came to similar conclusions. They indicated that the curd formation and its protein content resulted from the casein content and was related to the number of micelles, the number of which limited the outflow of the components with the whey.

Table 3. Chemical composition of (LSM, SEM) whey isolated from milk with different casein concentrations

\begin{tabular}{lccccc}
\hline \multicolumn{1}{c}{$\begin{array}{c}\text { Class of casein } \\
\text { content }- \text { CC }\end{array}$} & $\mathrm{n}$ & \multicolumn{3}{c}{ Chemical composition [\%] } \\
\cline { 3 - 5 } & & protein & fat & dry matter & solids-not-fat \\
\hline $\mathrm{A}<2.43 \%$ & 26 & 1.060 & 0.160 & 1.230 & 1.070 \\
$\mathrm{~B} \leq 2.43 \%$ & 35 & 0.970 & 0.140 & 1.120 & 0.960 \\
SEM & & 0.020 & 0.010 & 0.020 & 0.030 \\
P-value & & 0.016 & 0.056 & 0.024 & 0.015 \\
\hline
\end{tabular}

Król et al. (2011) found a higher total protein content (1.43\%) and dry matter $(6.63 \%)$ in rennet whey obtained from the milk of Holstein-Friesian cows when compared to our results. Johnson et al. (2001) demonstrated that the rate of coagulation also affected the whey and final product composition (total protein $-3.24 \%$, casein $-2.51 \%$ ) in the milk, which composition was similar to that in our study. The content of fat in the whey and water in the finished cheddar cheese in the study of these authors was similar to our results. They ranged from 0.156 to $0.175 \%$ and 46.44 to $48.90 \%$, respectively. In contrast to the discussed own results, Johnson et al. (2001) obtained a significantly higher protein content in the finished product, as it ranged from 30.92 to $32.08 \%$.

The correlation coefficient values in Table 4 indicate a significant impact of casein contained in pasteurized milk on the basic components in the final product. This is important information, especially since it has been shown a significant effect of casein content in raw milk on its content of pasteurized raw material (Table 1). The obtained values of the correlation coefficient regarding the dependencies studied (Table 4; $\mathrm{P}<0.05$ ) show that there is a strong positive correlation between the casein in milk and protein content, dry matter content and solid-not-fat content in cheese $(0.370-0.782 ; \mathrm{P}<0.05)$. Relatively strong negative correlation was found between the casein in milk and protein content, fat content, dry matter content and solid-notfat content in whey $(-0.435--0.726 ; P<0.05)$. Noteworthy are the relationships shown with $\mathrm{k}$-casein and the proportion of cazein/protein in raw milk and the content of ingredients in curd and whey. It was found that the higher content of casein and higher casein protein of pasteurized milk is accompanied by higher retention of ingredients in quark $(0.492-0.630$, $\mathrm{P}<0.05)$ and smaller whey $(-0.529--61313, \mathrm{P}<0.05)$. 
Table 4. Correlation coefficient values for the selected characteristics traits of pasteurized milk and the content of the main components of the curd and whey

\begin{tabular}{lccc}
\hline \multirow{2}{*}{ Traids analyzed } & \multicolumn{2}{c}{ Milk chemical composition [\%] } \\
\cline { 2 - 4 } & casein & K-casein & casein/ protein \\
\hline Cheese curds chemical composition [\%] & & & $0.630^{*}$ \\
\hline Protein & $0.702^{*}$ & $0.590^{*}$ & - \\
Fat & $0.370^{*}$ & - & $0.512^{*}$ \\
Dry matter & $0.782^{*}$ & $0.492^{*}$ & $0.538^{*}$ \\
Solid-not-fat & $0.710^{*}$ & - & $-0.590^{*}$ \\
\hline Whey chemical composition [\%] & & - & - \\
\hline Protein & $-0.681^{*}$ & $-0.612^{*}$ & $-0.582^{*}$ \\
Fat & $-0.435^{*}$ & $-0.595^{*}$ & $-0.529^{*}$ \\
Dry matter & $-0.726^{*}$ & $-0.613^{*}$ & $-0.675^{*}$ \\
Solid-not-fat & & & \\
\hline
\end{tabular}

${ }^{*} \mathrm{P}>0.05$

\section{CONCLUSSION}

The content of $\mathrm{k}$-casein and basic components in the pasteurized milk was significantly associated with casein content in raw milk. Lower losses were obtained during the separation of curd from the whey, as a result of the use of products containing more than $2.43 \%$ casein. The resultant curd and ripened cheese contained in a consequence higher protein and solidsnot-fat contents. The production of long ripening cheese from milk with casein content exceeding $2.43 \%$ allowed to increase cheese yield with a favorable protein/fat ratio.

The results suggest improving the quality of milk dedicated for cheese industry should primarily be carried with in order to obtain raw milk with casein content exceeding $2.43 \%$.

\section{REFERENCES}

Amenu B. 2004. Environmental and dietary effects on milk composition and cheddar cheese yield. PhD thesis, Brisbane, Australia, The University of Queensland (unpublished).

Amenu B., Deeth H.C. 2007. The impact of milk composition on cheddar cheese manufacture. Aust. J. Dairy Technol. 62, 171-184.

AOAC. 1995. Official methods of analysis. Arlington, VA, USA. Association of Official Analytical Chemists.

Barłowska J., Litwińczuk Z., Król J., Topyła B. 2006. Technological usefulness of milk of cows of six breeds maintained in Poland relative to a lactation phase. Pol. J. Food Nutr. Sci. 15, 17- 21.

Chmura S., Śmietana Z., Żulewska J. 2002. The effect of the production method on selected physicalchemical properties of cottage cheeses. Pol. J. Food Nutr. Sci. 11, 189-197.

Commission Regulation (EC) No. 1662/2006 of 6 November 2006 amending Regulation (EC) No. 853/2004 of the European Parliament and of the Council laying down specific hygiene rules for food of animal origin, https://publications.europa.eu/en/publication-detail/-/publication/ /befe5c7a-c8a0-4518-8742-dc3a1b891836/language-en, access:8.03.2019.

Considine T., Geary S., Kelly A.L., Mcsweeney P.L. 2002. Proteolytic specificity of cathepsin G on bovine $\alpha$ S1- and $\beta$-caseins. Food Chem. 76, 59-67. 
Correding M., Dalgleish D. 1999. The mechanism of the heat-induced interaction of whey proteins with casein micelles in milk. Int. Dairy J. 9, 233-236.

Dalgleish D., Goff D., Luan B. 2002. Exchange reactions between whey proteins and caseins in heated soya oil-in-water emulsion system - behavior of individual proteins. Food Hydrocoll. 16, 295-302.

Gustavsson F., Buitenhuis A.J., Johansson M., Bertelsen H.P., Glantz M., Poulsen N.A. 2014. Effects of breed and casein genetic variants on protein profile in milk from Swedish Red, Danish Holstein, and Danish Jersey cows. J. Dairy Sci. 97, 3866-3877.

Hallén E., Allmere T., Näslund J., Andrén A., Lundén A. 2007. Effect of genetic polymorphism of milk proteins on rheology of chymosin-induced milk gels. Int. Dairy J. 17, 791-799.

Havea P., Singh H., Creamer L.K. 2001. Characterization of heat-induced aggregates of $\beta$-lactoglobulin, $\alpha$-lactalbumin and bovine serum albumin in a whey protein concentrate environment. J. Dairy Res. 68, 483-497.

Ikonen T., Morri S., Tyrisevä A.M., Ruottinen O., Ojala M. 2004. Genetic and phenotypic correlations between milk coagulation properties, milk production traits, somatic cell count, casein content, and pH of milk. J. Dairy Sci., 87, 458-467.

Johnson M.E., Chen C.M., Jaeggi J.J. 2001. Effect of rennet coagulation time on composition, yield and quality of reduced-fat cheddar cheese. J. Dairy Sci. 84, 1027-2356.

Jurczak M.E. 2005. Mleko produkcja, badanie, przerób. Warszawa, SGGW. [in Polish]

Kowal M. 2013. Wpływ sezonu produkcji na przydatność technologiczną, profil kwasów tłuszczowych i zawartość cholesterolu w mleku pozyskiwanym od krów utrzymywanych w oborach wolnostanowiskowych i żywionych systemem TMR [Effect of production season on technological suitability, fatty acids profile and cholesterol content in milk of cows maintained in free-stall barns and fed according to the TMR system]. Rocz. Nauk. PTZ 9, 47-57. [in Polish]

Król J., Brodziak A., Litwińczuk A. 2011. Podstawowy skład chemiczny i zawartość wybranych białek serwatkowych w mleku krów różnych ras i w serwatce podpuszczkowej [Basic chemical composition and content of selected whey proteins in milk from different cow breeds and in rennet whey]. Żywn. Nauka Technol. Jakość 4, 74-83. [in Polish]

Larsen L.B., McSweeney P.L.H., Hayes M.G., Andersen J.B., Ingvartsen K.L., Kelly A.L. 2006. Variation in activity and heterogenity of bovine milk proteases with stage of lactation and somatic cell count. Int. Dairy J. 16, 1-8.

Larsen L.B., Rasmussen M.D., Bjerring M. Nielsen J.H. 2004. Proteases and protein degradation in milk from cows infected with Streptococcus uberis. Int. Dairy J. 14, 899-907.

Mackle T.R., Bryant A.M., Petch S.F., Hooper R.J., Auldist M.J. 1999. Variation in the composition of milk protein from pasture-fed dairy cows in late lactation and the effect of grain and silage supplementation. New Zeal. J. Agr. Res. 42, 147-154.

Młynek K., Oler A., Zielińska K., Tkaczuk J., Zawadzka W. 2018. The effect of selected components of milk and ripening time on the development of the hardness and melting properties of cheese. Acta Sci. Pol. Technol. Aliment. 17(2), 133-140.

Ng-Kwai-Hang K.F., Grosclaude F. 2003. Genetic polymorphism of milk proteins, in: Advanced dairy chemistry. Proteins. Ed. P.F. Fox, P.L.H. McSweeney. Boston, Springer, 739-816.

Sitkowska B., Wiśniewska E., Neja W. 2009. Genotyp beta-laktoglobuliny i kappa-kazeiny a użytkowość mleczna w laktacji maksymalnej [Beta-lactoglobulin and kappa-caseine genotype and milk yield in maximum lactation]. Zesz. Nauk. UTP Bydg. 252, 109-116. [in Polish]

St-Gelais D., Hache S. 2005. Effect of $\beta$-casein concentration in cheese milk on rennet coagulation properties, cheese composition and cheese ripening. Food Res. Int. 38, 523-531.

Verdi R.J., Barbano D.M., Dellavalle M.E., Senyk G.F. 1987. Variability in true protein, casein, nonprotein nitrogen and proteolysis in high and low somatic-cell milks. J. Dairy Sci. 70, 230-242.

Walstra P., Wouters J.T.M., Geurts T.J. 2006. Dairy science and technology. 2nd edition. London, Taylor and Francis Group, 687-709. 


\section{WPŁYW ZAWARTOŚCI KAZEINY W MLEKU SUROWYM NA RETENCJĘ PODSTAWOWYCH SKŁADNIKÓW W SUROWCU PO PASTERYZACJI I W TWAROGU}

Streszczenie. Celem doświadczenia była ocena wpływu zawartości kazeiny w mleku na wydajność serowarską oraz podstawowy skład chemiczny twarogu i migrację składników mleka do serwatki. Mleko pozyskiwano od krów rasy polskiej holsztyńsko-fryzyjskiej, żywionych w systemie TMR. Materiał badawczy stanowiło 61 próbek mleka pasteryzowanego w temperaturze $72^{\circ} \mathrm{C}$. W doświadczeniu uwzględniono jedynie surowiec o kwasowości 6,5-7,5 $\mathrm{SH}$ i spełniający normy cytologiczne. Mleko przed pasteryzacją oceniano pod względem zawartości kazeiny i zaliczano je do jednej z klas (CC). Wartość progową dla kazeiny ustalono na poziomie 2,43\%. Oceniano między innymi zawartość białka ogólnego, tłuszczu, suchej masy, k-kazeiny i uzysk twarogu. Analizowane cechy oznaczano w mleku surowym i pasteryzowanym, serwatce oraz w świeżym twarogu. Wyższa zawartość kazeiny w surowym mleku miała wpływ na większą retencję podstawowych składników w pasteryzowanym surowcu oraz w świeżym skrzepie, a wydzielona serwatka charakteryzowała się mniejszą zawartością białka. Wykazano również, że z mleka o większej zawartości kazeiny uzyskano więcej świeżego twarogu. W odniesieniu do efektywności przetwarzania mleka uzyskane wyniki należy uznać za informację mogącą służyć do wyznaczania w praktyce produkcyjnej minimalnej zawartości kazeiny w mleku serowarskim. Można uznać, że udział ten nie powinien być mniejszy niż 2,43\%.

Słowa kluczowe: krowa, kazeina, skład mleka, serwatka, twaróg. 
